\title{
A DIDÁTICA QUE EMERGE DA PEDAGOGIA DO OPRIMIDO
}

\author{
GIOVEDI, Valter Martins ${ }^{\mathrm{i}}$
}

SILVA, Itamar Mendes daii

AMARAL, Débora Monteiro do

\begin{abstract}
RESUMO
Uma leitura atenta do livro Pedagogia do Oprimido nos leva a constatar que o termo "Didática" não aparece de forma explícita na principal obra de Paulo Freire. No entanto, isso não significa que não exista uma Didática proposta nesta obra. Neste ensaio, que se caracteriza como produto coletivo de debates, discussões de estudo e investigações, apresentamos os resultados alcançados na busca por sistematizar a Didática que dela emerge. Nos estudos realizados, buscamos responder os seguintes questionamentos: É possível afirmar a existência de uma Didática Freireana? No que consiste a Didática Crítico-Libertadora de Paulo Freire presente na obra Pedagogia do Oprimido? Nossos estudos indicaram que responder à segunda questão requer compreender a Didática Freireana em duas dimensões: dos seus pressupostos e dos seus elementos constituintes. Os pressupostos são políticos, axiológicos, gnosiológicos e epistemológicos. Os elementos constituintes são conteúdos, métodos, avaliação e relações educador-educandos. Dessa forma, propomos o conceito de Didática Crítico-Libertadora como: encontro dialógico de sujeitos, educadores(as)-educandos(as) e educandos(as)-educadores(as), que realizam seus atos cognoscentes no contexto de aula, mediatizados pelo mundo, dialetizado pela relação entre liberdade e autoridade, tendo como ponto de partida a percepção de realidade dos(as) educandos(as) sobre suas situações-limites, que se encontra e confronta com a percepção do(a) educador(a), que identificando as situações-limites seleciona conhecimentos crítico-significativos, e que tem como horizonte ético-político a inserção crítica (práxis transformadora) dos sujeitos coletivos em favor da transformação social a partir da superação da realidade opressora como condição para a realização da vocação do ser humano para "ser mais".
\end{abstract}

PALAVRAS-CHAVE: Paulo Freire. Didática Crítico-Libertadora. Pedagogia do Oprimido. Didática.

\footnotetext{
*Doutor em Educação: Currículo pela PUC -SP. É professor do Centro de Educação da Universidade Federal do Espírito Santo (CE - UFES). E-mail: giovedival@ gmail.com

${ }^{* *}$ Doutor em Educação: Currículo pela PUC -SP. Professor do Centro de Educação da Universidade Federal do Espírito Santo (CE - UFES). E-mail: itamar.mendes@ufes.br

*** Doutora pela Universidade Federal de São Carlos (UFSCar). Professora do Centro de Educação da Universidade Federal do Espírito Santos (CE - UFES). E-mail: deboramdoamaral@gmail.com
} 


\title{
$e$-Curriculum
}

Programa de Pós-Graduação em Educação: Currículo

THE DIDACTICS EMERGING FROM THE PEDAGOGY OF THE OPPRESSED

GIOVEDI, Valter Martins*

SILVA, Itamar Mendes da**

AMARAL, Débora Monteiro do ${ }^{* * *}$

\begin{abstract}
An attentive reading of the book Pedagogy of the Oppressed leads us to verify that the term "didactics" does not appear explicitly in the main work of Paulo Freire. However, this does not mean that there is no Didactics proposed in this work. In this essay, which is characterized as a collective product of debates, study discussions and investigations, we present the results achieved in seeking to systematize the Didactics that emerge from it. In the studies carried out, we tried to answer the following questions: Is it possible to affirm the existence of a Freirean Didactics? What is Paulo Freire's Critical-Liberatory Didactics about in the work Pedagogy of the Oppressed? Our studies indicated that answering the second question requires understanding of the Freirean Didactics in two dimensions: their key underlying assumptions and its contents. The assumptions are political, axiological, gnosiological and epistemological. These contents are the content itself, methods, evaluation and educator-student relationships. In this way, we propose the concept of Critical-Liberatory Didactics as: a dialogical encounter of subjects, educators-students and students-educators, who perform their cognitive acts in the classroom context, mediated by the world, dialected by the relation between freedom and authority, starting from the learners' perception of reality, which meets and confronts the educator's perception, who, by identifying the limit-situations, selects critical-significant knowledge, and by having an ethicalpolitical horizon seeks the critical insertion (transforming praxis) of the subjects aiming social transformation from the overcoming of the oppressive reality as a condition to achieve the vocation of the human being to "be more".
\end{abstract}

KEYWORDS: Paulo Freire. Critical-Liberatory Didactics. Pedagogy of the Oppressed. Didactics.

\footnotetext{
* Doctor of Education: Curriculum by PUC-SP. Teacher at the Education Center of the Federal Universisty of Espírito Santo (CE - UFES).E-mail: giovedival@gmail.com

${ }^{* *}$ Doctor of Education: Curriculum by PUC-SP. Teacher at the Education Center of the Federal University of Espírito Santo (CE - UFES).E-mail: itamar.mendes@ufes.br

${ }^{* * *}$ Doctor from the Federal University of São Carlos (UFSCar). Teacher at the Education Center of the Federal University of Espirito Santo (CE - UFES). E-mail: deboramdoamaral@gmail.com
} 


\section{INTRODUÇÃO}

Uma leitura atenta do livro Pedagogia do Oprimido nos leva a constatar que o termo "Didática" não aparece de forma explícita na principal obra de Paulo Freire. Aliás, incursionando por outras obras de Freire, podemos perceber que essa expressão foi muito pouco colocada em evidência por ele. Para se referir ao campo que mais tem sido objeto de preocupações da Didática, Freire recorreu aos termos "prática educativa" ou "prática pedagógica".

A falta de referências diretas de Freire ao termo Didática contribuiu para ancorar afirmações de que sua obra não se refere à educação formal. Porém, a leitura atenta de suas obras realizada no âmbito de coletivo de pesquisadores(as) e estudantes que se reúnem quinzenalmente com esta finalidade, bem como nossas próprias experiências pedagógicas em sala de aula referenciadas na perspectiva freireana, convenceram-nos de que faz todo o sentido falar em Didática Freireana que denominamos: Didática Crítico-Libertadora.

A problematização da temática foi motivada pela percepção de que é comum no imaginário de docentes que atuam na educação formal a ideia de que a Pedagogia de Paulo Freire não serve para a educação formal, seja na Educação Básica ou no Educação Superior. Essa percepção tem levado muitos profissionais da educação formal a simpatizarem com as ideias de Freire, porém não considerarem sua proposta na hora de planejar o trabalho e de efetivar a prática pedagógica. É como se a concepção de Paulo Freire só servisse para proferir ideias genéricas, slogans e citações em momentos celebrativos. No entanto, na hora de tomar as decisões pedagógicas sobre a organização do trabalho em sala de aula, recorre-se a outras fontes, quase sempre prescritivas e, por vezes, contrárias às ideias freireanas como: atividades conteudísticas e/ou desconectadas da realidade, elaboradas por autores de apostilas ou livros didáticos etc.

Dito de outra forma, constata-se a que hegemonia de uma Didática prescrita vem pautando as ações pedagógicas da maioria dos(as) educadores(as). E, nesse sentido, a Didática hegemônica retira dos sujeitos concretos do trabalho pedagógico a possibilidade de serem os principais autores da própria prática.

Ora, há caminhos que podemos trilhar no sentido de resistir e criar alternativas a essa Didática hegemônica. Ou seja, o fazer pedagógico no contexto da educação formal pode sim ser planejado e efetivado com base em outros princípios e conceitos. A perspectiva de Paulo 


\section{$e$-Curriculum}

Freire nos oferece um arcabouço conceitual e praxiológico bem fundamentado e coeso para propor uma Didática que dispute as narrativas e as práticas no campo da educação formal.

Neste ensaio, trazemos resultados alcançados nos estudos e debates que vimos realizando sobre o livro Pedagogia do Oprimido, especialmente, quando estamos iniciando as atividades comemorativas dos 50 anos de sua primeira edição. Pretendemos buscar, com a ousadia a que Paulo Freire nos incita, não a reprodução de suas ideias, mas recriações possíveis de sua obra e/ou desenvolver aspectos particulares que foram por ele anunciados, mas que por motivos variados não foram desenvolvidos. Se fomos ou não capazes de fazê-lo serão os(as) leitores(as) deste ensaio que poderão dizer.

Na leitura e debates que realizamos buscamos responder aos seguintes questionamentos: É possível afirmar a existência de uma Didática Freireana? No que consistiria essa Didática, que seria Crítico-Libertadora, presente na obra Pedagogia do Oprimido?

Essas perguntas se desdobram em algumas outras: Que conceito de Didática CríticoLibertadora emerge da Pedagogia do Oprimido? Quais os fundamentos dessa Didática? Quais seus elementos constituintes? Quais as implicações da Didática Crítico-Libertadora de Paulo Freire para a prática pedagógica?

Importante destacar que neste texto esforçamo-nos por responder essas questões, como parte de um projeto mais amplo de sistematizar a concepção freireana de Didática, tendo em vista contribuir com o fortalecimento da presença da perspectiva de Paulo Freire nos contextos de educação formal tanto na escola básica quanto na educação superior.

\section{A QUÊ NOS REFERIMOS QUANDO FALAMOS DE DIDÁTICA}

O estudo da Didática no Brasil tem sido marcado, desde os anos 1980, pela falta de consenso em relação ao seu objeto, conceito e à sua abrangência (CANDAU, 2012). A variedade de concepções de Didática não é difícil de perceber quando nos dedicamos a estudar alguns textos (MATOS, 2009; CANDAU, 2012; CASTRO; CARVALHO, 2001; LIBÂNEO, 2012; SAUL; SAUL, 2017) e manuais de Didática (LIBANEO, 1994; CORDEIRO, 2009; MELO e URBANETZ, 2012; GASPARIN, 2011). Por isso, não é simples e evidente a resposta para a questão que nomeia este item: "a que nos referimos quando falamos de Didática?”. Enfrentá-la exige fazer opções. E toda opção nos obriga a privilegiar certos aspectos em detrimento de outros. 
Entendemos a Didática como uma das dimensões da ação educativa, dentre outras existentes, quando falamos em educação formal, tais como: a Política, a Gestão, o Currículo, a Metodologia de Ensino, a Avaliação etc. Ou seja, compreendemos que a Didática é permanentemente condicionada pelas decisões e ações que se dão no campo da política, da gestão, do currículo, da estrutura organizacional, da avaliação etc., assim como também é condicionada por processos sociais mais amplos (políticos, econômicos, culturais, étnicoraciais, ambientais, religiosos, linguísticos, psíquicos etc.) que influenciam diretamente na formação da identidade de educadores(as) e estudantes a quem a Didática se dirige.

Apesar dessas múltiplas esferas intervenientes no campo da ação e do pensar didáticos, entendemos que é possível delimitar a especificidade da Didática. A Didática diz respeito mais diretamente ao conjunto de intenções, planos e ações de ensino-aprendizagem que se dão em função do e no contexto de aula. Ou seja, a Didática estende sua influência desde o momento em que o(a) educador(a) começa a refletir sobre os seus pressupostos e intenções políticopedagógicas, continua no processo em que o(a) educador(a) elabora seus planos de ação pedagógica e se revela de modo mais visível no momento em que educador(a) e educandos(as) se encontram no contexto de aula. Assim, quando falamos de Didática, referimo-nos a toda a teoria e a prática do ensino no contexto de aula.

As diversas teorias e concepções educacionais, de modo explícito ou não, invariavelmente sugerem pressupostos, caminhos e objetivos para o ato de ensinar. O que nos faz concluir que todas elas, de algum modo, tocam na questão da Didática, de seu objeto e de sua questão nuclear: o que é e como pode ser o ensino?

Nessas afirmações corroboramos com expressivo conjunto de estudiosos da Didática quando afirmam o ensino como seu núcleo central, pois não é possível existir uma prática de ensino concreta desprovida de elementos didáticos. Ou seja, a Didática, de modo mais ou menos consciente, está sempre presente na ação concreta de quem ensina algo a alguém. Isto posto, passamos agora a refletir sobre os pressupostos e os elementos constituintes da Didática.

Mais uma vez é preciso demarcar que não há consenso sobre quais são esses pressupostos e elementos. E, mais uma vez, deparamo-nos com a difícil tarefa de selecionar aqueles que acreditamos serem os mais significativos para os fins deste trabalho. Assim, em busca de nos aproximarmos das opções necessárias, apresentamos quatro pressupostos da Didática no quadro a seguir. 


\section{$e$-Curriculum}

Programa de Pós-Graduação em Educação: Currículo

Quadro 1 - Pressupostos da Didática

\begin{tabular}{|l|l|l|l|}
\hline \multicolumn{1}{|c|}{ Políticos } & \multicolumn{1}{|c|}{ Axiológicos } & \multicolumn{1}{c|}{ Gnosiológicos } & \multicolumn{1}{c|}{ Epistemológicos } \\
\hline $\begin{array}{l}\text { - Ensinar para qual } \\
\text { mundo? Ensinar para } \\
\text { qual sociedade? }\end{array}$ & $\begin{array}{l}\text { - Ensinar quais } \\
\text { valores? }\end{array}$ & $\begin{array}{l}\text { - O que é o aprender? } \\
\text { Como as pessoas } \\
\text { aprendem? }\end{array}$ & $\begin{array}{l}\text { - Quais } \\
\text { conhecimentos } \\
\text { importam para o } \\
\text { espaço pedagógico da } \\
\text { aula? }\end{array}$ \\
\hline $\begin{array}{l}\text { - a sociedade que se } \\
\text { quer construir. }\end{array}$ & $\begin{array}{l}\text { - o sujeito que se quer } \\
\text { formar. }\end{array}$ & $\begin{array}{l}\text { - visão a respeito do } \\
\text { processo de } \\
\text { conhecimento. }\end{array}$ & $\begin{array}{l}\text { - visão a respeito de } \\
\text { qual conhecimento } \\
\text { deve ser ensinado. }\end{array}$ \\
\hline
\end{tabular}

Fonte: Elaborado pelos autores.

No quadro seguinte, apresentamos quatro elementos constituintes da Didática.

Quadro 2 - Elementos constituintes da Didática

\begin{tabular}{|c|c|c|c|}
\hline \multicolumn{4}{|c|}{ Aspectos que explicitam a concepção de ensino praticada pelo(a) educador(a) } \\
\hline teúdos Con & Métodos & Avaliação & $\begin{array}{c}\text { Relações } \\
\text { interpessoais }\end{array}$ \\
\hline que ensinar? & - Como ensinar? & $\begin{array}{l}\text { - Como qualificar o } \\
\text { trabalho feito? }\end{array}$ & $\begin{array}{l}\text { - Como se relacionar } \\
\text { com os estudantes na } \\
\text { convivência com eles } \\
\text { em aula? }\end{array}$ \\
\hline $\begin{array}{l}\text { os tópicos dão } \\
\text { conhecimentos que se } \\
\text { propõe para o trabalho } \\
\text { pedagógico junto } \\
\text { aos(às) educandos(as) } \\
\text { no contexto escolar. }\end{array}$ & $\begin{array}{lr}\text { - são os caminhos que } \\
\text { escolhemos para } \\
\text { desenvolver certos } \\
\text { conteúdos em função } \\
\text { de } & \text { finalidades } \\
\text { almejadas. }\end{array}$ & $\begin{array}{l}\text { - é a atribuição de um } \\
\text { valor (não } \\
\text { necessariamente } \\
\text { quantitativo) a } \\
\text { determinado fato, ato, } \\
\text { processo, } \\
\text { acontecimento, } \\
\text { trabalho etc. com base } \\
\text { em uma expectativa } \\
\text { prévia. }\end{array}$ & $\begin{array}{l}\text { - é o modo pelo qual, } \\
\text { no processo de ensino, } \\
\text { educadores(as) } \\
\text { interagem com os(as) } \\
\text { estudantes. }\end{array}$ \\
\hline
\end{tabular}

Fonte: Elaborado pelos autores.

Com esses quadros, queremos circunscrever alguns aspectos que se sobressaem na reflexão sobre a Didática. Queremos mostrar que, por um lado, a Didática se expressa no planejamento e nas práticas pedagógicas do professor no contexto de aula, o que fica evidenciado nos elementos enumerados no Quadro 2. Por outro lado, ela se sustenta em certas 
crenças e fundamentos (políticos, axiológicos, gnosiológicos, epistemológicos etc.) deste planejamento e dessas práticas (Quadro 1).

Quando vemos um(a) professor(a) em plena atividade de aula, estamos observando, poderíamos dizer, a sua Didática em ação; quando nos concentramos nas intencionalidades do(a) professor(a) e nos abrimos para escutar as razões de suas escolhas, estamos tomando contato com a Didática projetada pelo(a) educador(a). Em outros termos, a Didática abrange as teorias (os pressupostos) que fundamentam a aula e a prática pedagógica decorrente (os elementos constituintes) e desenvolvida no contexto de aula.

Vale a pena repetir: outros aspectos poderiam ser elencados tanto no que concerne aos pressupostos da Didática (Quadro 1), quanto no que tange aos seus elementos constituintes (Quadro 2). Nossa opção por colocar esses aspectos em evidência se deu por entendermos que são fundamentais e porque sobre eles(as) Freire assumiu posições na Pedagogia do Oprimido, o que nos ajuda no trabalho de explicitar a Didática Crítico-Libertadora.

De início destacamos na denúncia de Freire à Educação Bancária referência direta e indireta aos pressupostos e elementos da Didática que pretendemos abordar, pois é da crítica à maneira de organização da escola que Paulo Freire vai apresentando suas propostas para a Educação Crítico-Libertadora que tem uma forma pedagógica de se organizar e de se fazer e refazer no processo de composição da aula. Eis a reflexão proposta por ele:

Daí, então, que nela [na Educação Bancária]:

a) o educador é o que educa; os educandos, os que são educados;

b) o educador é que sabe; os educandos, os que não sabem;

c) o educador é que pensa; os educandos, os pensados;

d) o educador é que diz a palavra; os educandos os que a escutam docilmente;

e) o educador é o que disciplina; os educandos, os disciplinados;

f) o educador é o que opta e prescreve sua opção; os educandos, os que seguem a prescrição;

g) o educador é o que atua; os educandos, os que têm a ilusão de que atuam, na atuação do educador;

h) o educador escolhe o conteúdo programático; os educandos, jamais ouvidos nessa escolha, se acomodam a ele;

i) o educador identifica a autoridade do saber com sua autoridade funcional, que opõe antagonicamente à liberdade dos educandos; estes devem adaptarse às determinações daquele;

j) o educador, finalmente, é o sujeito do processo; os educandos meros objetos (2005b, p. 68).

Desta síntese feita por Freire da relação professor/aluno/conhecimento/vida, suas naturezas e lugares no processo de ensino-aprendizagem, é possível iniciarmos o debate, a partir das opções feitas, em torno dos pressupostos da Didática (quadro 1) e seus elementos 


\section{$e$-Curriculum}

Programa de Pós-Graduação em Educação: Currículo

constitutivos (quadro 2). No quadro que segue propomos a identificação, neste excerto, das afirmações que dizem respeito à Didática em cada um dos itens desde o primeiro destacado com a letra "a" até o último designado "j".

Quadro 3 - Pressupostos e elementos da Didática presentes na citação de Freire (2005, p. 68)

\begin{tabular}{|c|c|c|c|}
\hline Axiológicos & Políticos & Gnosiológicos & Epistemológicos \\
\hline (j) & (i) & (a), (c) & (b) \\
\hline Conteúdos & Métodos & Avaliação & Relações interpessoais \\
\hline (h) & (d), (g) & (f) & (e) \\
\hline
\end{tabular}

Fonte: Elaborado pelos autores.

É claro que o excerto e o quadro comportam outras classificações possíveis. No entanto, parece-nos bastante evidente que considerações a respeito da Didática estão presentes nas proposições de denúncia e nos anúncios de Paulo Freire na Pedagogia do Oprimido.

Na nossa interpretação, o item (j) expressa a dimensão axiológica na medida em que nele sobressai, em última instância, a objetificação do ser humano promovida pela Educação Bancária, colocando-se a serviço de uma ética da desumanização. É exatamente a partir dessa crítica que Freire constrói sua proposta de humanização, centro de sua teoria pedagógica e de conhecimento, e donde decorrem os demais pressupostos.

O item (i) expressa a dimensão política, pois nele fica evidenciada a naturalização da hierarquia entre educador(a) e educandos(as) quanto ao exercício do poder em relação ao conhecimento e em relação à organização do espaço coletivo. Na Educação Bancária, o(a) professor(a) é o exclusivo detentor do poder político.

Os itens (a) e (c) evidenciam aspectos gnosiológicos da Educação Bancária já que revelam certo modo de compreender o papel dos sujeitos no processo de conhecimento. Para a Educação Bancária, trata-se de um papel de passividade, em que os(as) estudantes são entendidos como meros receptores de conteúdos e valores.

No item (b) fica bem evidenciada a dimensão epistemológica, revelando-se claramente o não reconhecimento da Educação Bancária dos conhecimentos que os(as) educandos(as) construíram em suas vidas e que carregam para o contexto pedagógico. 
No item (h) o modo de seleção dos conteúdos da Educação Bancária se expressa de modo explícito. Educandos(as) ficam a mercê de um processo de seleção que é indiferente a eles(as).

Nos itens (d) e (g) sobressai-se o método da Educação Bancária: unilateral, unidirecional, mera transmissão: professor(a) transfere, educando(a) absorve e reproduz. O(A) primeiro atua, o(a) segundo(a) é expectador(a).

No item (f) evidencia-se o que se espera do(a) educando(a) da Educação Bancária. Seguidores dóceis de prescrições, comportamentos domesticados, obediência servil, repetição das lições dadas. Por isso, neste item entendemos que está evidenciada a dimensão da avaliação.

Por fim, no item (e), fica evidenciada a denúncia de Freire ao modo pelo qual a Educação Bancária compreende as relações interpessoais educador(a)-educandos(as). A disciplina concebida como subserviência às ordens provenientes do autoritarismo docente.

Com esses comentários, pretendemos fazer apenas uma primeira aproximação às questões que serão trazidas no decorrer deste ensaio. Com eles, esperamos ter demonstrado que os problemas da Didática estão colocados por Freire no excerto supracitado. Portanto, há muita pertinência em falarmos em Didática a partir da perspectiva freireana.

Os dois próximos itens seguirão uma mesma lógica de exposição. Trataremos dos pressupostos (item 3) e dos elementos (item 4), buscando explicitar em cada um deles a denúncia e o anúncio. Ou seja, evidenciaremos, primeiro, a perspectiva rejeitada por Freire para, em seguida, apresentarmos a proposta defendida. Assim, pretendemos contribuir com a explicitação do confronto de perspectivas Didáticas que está presente na Pedagogia do Oprimido.

\section{FUNDAMENTOS DA DIDÁTICA FREIREANA NA PEDAGOGIA DO OPRIMIDO}

\subsection{Fundamentos axiológicos da Didática Crítico-Libertadora}

Quando nos referimos a fundamentos axiológicos da Didática Crítico-Libertadora de Paulo Freire, precisamos ter clareza de que estamos nos perguntando sobre: qual a concepção ética que se encontra no pensamento de Paulo Freire? Em favor de quais valores e contra quais valores Paulo Freire se posiciona? Quais exigências éticas são apresentadas aos indivíduos e às coletividades humanas? 


\section{e-Curriculum}

Programa de Pós-Graduação em Educação: Currículo

O problema de sua humanização, apesar de sempre haver sido, de um ponto de vista axiológico, o seu problema central, assume, hoje, caráter de preocupação ineludível. [...] Humanização e desumanização, dentro da história, num contexto real, concreto, objetivo, são possibilidades dos homens como seres inconclusos e conscientes de sua inconclusão.

Mas, se ambas são possibilidades, só a primeira nos parece ser o que chamamos de vocação dos homens. Vocação negada, mas também afirmada na própria negação. Vocação negada na injustiça, na exploração, na opressão, na violência dos opressores. Mas afirmada no anseio de liberdade, de justiça, de luta dos oprimidos, pela recuperação de sua humanidade roubada.

A desumanização, que não se verifica apenas nos que têm a sua humanidade roubada, mas também, ainda que de forma diferente, nos que a roubam, é distorção da vocação do ser mais. [...] A luta pela humanização, pelo trabalho livre, pela desalienação, pela afirmação dos homens como pessoas, como "seres para si”, não teria significação. Esta somente é possível porque a desumanização, mesmo que um fato concreto na história, não é, porém, destino dado, mas resultado de uma "ordem" injusta que gera a violência dos opressores e esta, o ser menos (2005b, p. 31-32).

A manutenção e desenvolvimento da vida humana não ocorre sob quaisquer circunstâncias. Para que a vida possa se perpetuar precisa que necessidades animais sejam atendidas: comida, água, abrigo, descanso, convivência etc.

Necessidades propriamente humanas também precisam ser atendidas: afeto, carinho, lazer, dizer a própria palavra (direito de expressão), participação política, acesso à informação etc.

O termo "necessidades" evidencia que a humanização depende de sua presença e satisfação. A não satisfação produz a situação em que a vida dos seres humanos é eliminada ou fica reduzida a um nível de degradação que impede o exercício da liberdade. Ora, a liberdade é o que nos define como humanos, já que é a partir dela que criamos e recriamos nossa vida social, fazendo história. Por isso, toda e qualquer forma de vida social que impeça ou dificulte o acesso aos bens necessários à vida e ao desenvolvimento da liberdade contraria a vocação humana para "ser mais".

Por isso, a ética de Freire é aquela que reconhece no gênero humano certas necessidades universais que devem ser garantidas a todos e todas. O processo gradativo em que cada vez mais tais necessidades são atendidas chama-se humanização. Quanto mais conquistamos níveis elevados de humanização, tanto mais somos humanos: eis aí o significado profundo do "ser mais".

A esse projeto que, para Freire, a educação deve servir. Um projeto de libertação. Um projeto de humanização. Esse é o valor maior que rege toda a construção da Pedagogia e da Didática Crítico-Libertadoras de Paulo Freire. 


\subsection{Fundamentos políticos da Didática Crítico-Libertadora}

Ao nos concentrarmos nos fundamentos políticos da Didática Freireana, estamos diante das seguintes questões: qual é a perspectiva social, política e econômica defendida por Paulo Freire? A favor de qual sociedade e contra qual sociedade Paulo Freire se posiciona?

Na Pedagogia do Oprimido, Freire faz a denúncia da sociedade opressora. A sociedade opressora é aquela em que o seu funcionamento regular no âmbito econômico, político, social e cultural é marcado pela violência, entendida como redução dos sujeitos à condição de objetos. Portanto, a violência se expressa no autoritarismo, na exploração, na exclusão, nos preconceitos e em todas as formas sutis de naturalização de privilégios como a meritocracia que, supervalorizando eficiência e eficácia, pretende ganhar a aparência de recompensa ao esforço. A experiência histórica da sociedade opressora tende a produzir o sentimento de que as relações de opressão são naturais e mantém a ordem, como sinônimo de permanência e estabilidade social.

Freire tem clareza de que a opressão é causada por mecanismos estruturais da nossa sociedade que distorcem o sentido do que é justo socialmente: o latifúndio, a exploração, a cultura da colonização, o patriarcado, o etnocentrismo, os preconceitos e autoritarismos de toda ordem etc. Por isso, a superação da opressão não está ligada tão-somente a mudanças nas ideias dos indivíduos, mas, sobretudo, nas práticas das instituições sociais e das organizações coletivas (trabalho, família, escola, universidade, comunidade, mídia, Estado etc.). Em sociedades opressoras, as relações entre opressores e oprimidos tendem a atravessar todos os espaços da vida social, sustentando-se em uma desigual distribuição do poder, da riqueza e do acesso e à difusão dos bens culturais.

Os que concentram o poder social, econômico, político e cultural tendem a tratar os excluídos desses poderes como seres inferiores que, portanto, devem lhes servir.

A libertação, por isso, é um parto. E um parto doloroso. O homem que nasce deste parto é um homem novo que só é viável na e pela superação da contradição opressores-oprimidos, que é a libertação de todos. [...]

Esta superação não pode dar-se, porém, em termos puramente idealistas. Se se faz indispensável aos oprimidos, para a luta por sua libertação, que a realidade concreta de opressão já não seja para eles uma espécie de "mundo fechado" (em que se gera o seu medo da liberdade) do qual não pudessem sair, mas uma situação que apenas os limita e que eles podem transformar, é fundamental, então, que, ao reconhecerem o limite que a realidade opressora lhes impõe, tenham, neste reconhecimento, o motor de sua ação libertadora. (FREIRE, 2005b, p. 38-39). 


\section{$e$-Curriculum}

Programa de Pós-Graduação em Educação: Currículo

Assim, para Freire, a superação da sociedade opressora deve se realizar nos âmbitos subjetivos e objetivos e a educação tem um papel a cumprir nesse processo, já que a sociedade opressora é legitimada por processos educacionais que reproduzem as relações sociais hegemônicas vigentes na sociedade.

Não é de estranhar, pois, que nesta visão "bancária" da educação, os homens sejam vistos como seres da adaptação, do ajustamento. Quanto mais se exercitarem os educandos no arquivamento dos depósitos que lhes são feitos, tanto menos desenvolverão em si a consciência crítica de que resultaria a sua inserção no mundo, como transformadores dele. Como sujeitos.

Quanto mais lhes imponha passividade, tanto mais ingenuamente, em lugar de transformar, tendem a adaptar-se ao mundo, à realidade parcializada nos depósitos recebidos (FREIRE, 2005b, p. 68).

A vida social almejada por Freire se revela na expressão "superação da situação de opressão", que se dá a partir da práxis transformadora que, no limite, deve se prolongar em práxis revolucionária. Portanto, seu horizonte político é de superação constante das estruturas e dos mecanismos que impedem a vida digna, a humanização.

São os oprimidos os maiores interessados nesse processo. Por isso, a construção de cada um dos passos no sentido dessa sociedade deve ser coletiva, por meio de relações simétricas de poder, sem concessões aos artifícios políticos (dirigismo, messianismo, populismo, elitismo etc.) e pedagógicos (Educação Bancária) próprios dos opressores.

\subsection{Fundamentos gnosiológicos da Didática Crítico-Libertadora}

Como se dá o conhecimento entre os seres humanos? Como se dá aprendizagem entre os seres humanos? Como se dá a relação entre o sujeito e o objeto do conhecimento? Essas são algumas questões tratadas pela dimensão gnosiológica da Didática. Ou seja, toda ação Didática possui de modo mais ou menos consciente certa teoria do conhecimento que a fundamenta e justifica suas decisões.

Freire foi explícito quanto à teoria de conhecimento que rejeita:

[A Educação Bancária] Sugere uma dicotomia inexistente homem-mundo. Homens simplesmente no mundo [...] Homens espectadores [...] Concebe a sua consciência como algo especializado neles [...] A consciência como se fosse alguma seção "dentro" dos homens, mecanicistamente compartimentada, passivamente aberta ao mundo que a irá "enchendo" de realidade (FREIRE, 2005b, p. 72-73).

A educação que se impõe aos que verdadeiramente se comprometem com a libertação não pode fundar-se numa compreensão dos homens como seres vazios a quem o mundo "encha" de conteúdos; não pode basear-se numa 
consciência espacializada, mecanicistamente compartimentada (FREIRE, 2005b, p. 77, grifos nossos).

Quando se dicotomiza a consciência dos sujeitos do mundo no qual esses mesmos sujeitos vivem e ao qual se referem atribuindo sentido, surge uma compreensão equivocada do processo de conhecimento. Passa-se a pressupor que os sujeitos são entidades abstratas e desencarnadas de uma realidade, concluindo-se que suas consciências estão aí totalmente à disposição para ser "enchidas" de conteúdos independentemente do seu sentido.

Essa é a gnosiologia que justifica a Didática genérica indiferente às realidades locais dos(as) educandos(as) e às suas visões de mundo. Justifica também as diversas propostas de padronização curricular nos diversos níveis: municipais, estaduais ou nacional.

Ao contrário da bancária, a educação problematizadora, respondendo à essência do ser da consciência, que é sua intencionalidade, nega os comunicados e existencia a comunicação. Indentifica-se com o próprio da consciência que é sempre ser consciência de, não apenas quando se intenciona aos objetos, mas também quando se volta sobre si mesma, no que Jaspers chama de "cisão". Cisão em que a consciência é consciência de consciência (FREIRE, 2005b, p. 77, grifos nossos).

Como situação gnosiológica, em que o objeto cognoscível, em lugar de ser o término do ato cognoscente de um sujeito, é o mediatizador de sujeitos cognoscentes, educador, de um lado, educandos, de outro, a educação problematizadora coloca, desde logo, a exigência da superação da contradição educador-educandos. Sem esta, não é possível a relação dialógica, indispensável à cognoscibilidade dos sujeitos cognoscentes, em torno do mesmo ato cognoscível. [...] a concepção "bancária" nega a dialogicidade como essência da educação e se faz antidialógica; para realizar a superação, a educação problematizadora - situação gnosiológica - afirma a dialogicidade e se faz dialógica (FREIRE, 2005b, p. 78, grifos nossos).

Dessas citações de Freire podemos extrair os seus ensinamentos gnosiológicos ou sua teoria do conhecimento. A aprendizagem não ocorre na passividade. A construção do conhecimento e a aprendizagem se dão a partir de um ato de conhecimento dos aprendizes. $\mathrm{Ou}$ seja, os(as) educandos(as) são sujeitos encarnados em um mundo que os provoca, que os condiciona, que lhes ensina coisas muito antes de chegarem ao contexto de aula. Suas consciências já realizaram infinitos movimentos de significações. Diante disso, como é possível acreditar que essas consciências simplesmente estão disponíveis para aprender sem que continuem como produtoras autônomas do sentido?

De fato, para Freire, isso não é possível. O compromisso real com o conhecimento/ aprendizagem exige por parte dos(as) educadores(as) a compreensão de que o processo se dá por atos de conhecimento dos(as) educandos(as) que não podem ser realizados, senão por 


\section{$e$-Curriculum}

eles(as) mesmos(as). Os atos de conhecimento ocorrem por intermédio do diálogo. Sem diálogo eles não ocorreriam. Tal como veremos adiante, o objeto do diálogo é a realidade existencial concreta dos sujeitos.

É a problematização dessa realidade promovida pela ação Didática do(a) educador (a) que fomenta o movimento da consciência em direção à compreensão de objetos cognoscíveis. Para Freire, o educador progressista deve ter em mente que, quando se encontra numa relação de ensino-aprendizagem libertadora, seu papel é o de problematizar o mundo/ a realidade concreta, os conhecimentos de experiência feitos que são trazidos para dentro da sala de aula pelos(as) educandos(as). É uma espécie de provocação, de desafio, que o educador(a) faz aos(às) educandos(as) para que mirem os seus olhares atentamente para aspectos de sua realidade que haviam passado despercebidos (ou acriticamente percebidos) e que, no entanto, estão presentes em sua situação existencial concreta. O conhecimento só é possível se o educador possibilitar que o ato de conhecimento dos educandos realmente se efetive, por meio da interação com os objetos de conhecimento. Tal interação possibilita o ato criativo, transformador, inventivo por parte daqueles que são sujeitos do processo. E tais atos possibilitam o conhecimento.

Em suma: não é possível esperar que ocorra a aprendizagem quando se desconhece e se nega a possibilidade de realização dos atos cognoscentes aos sujeitos a quem se pretende ensinar. Por isso tudo, o diálogo é exigência metodológica do processo de ensinoaprendizagem.

\subsection{Fundamentos epistemológicos da Didática Crítico-Libertadora}

A ação Didática implica no trabalho com o conhecimento. Porém, com qual conhecimento? Quais conhecimentos servem aos propósitos axiológicos e políticos anunciados e respeitam os pressupostos gnosiológicos apresentados anteriormente? Qual a validade dos conhecimentos? Há uma hierarquia entre eles?

Sobre essas questões, Freire (2005b) traz, na Pedagogia do Oprimido, algumas contribuições muito claras:

Nosso papel não é falar ao povo sobre a nossa visão do mundo, ou tentar impô-la a ele, mas dialogar com ele sobre a sua e a nossa. Temos de estar convencidos de que sua visão do mundo, que se manifesta nas várias formas de sua ação, reflete a sua situação no mundo, em que se constitui. A ação educativa e política não pode prescindir do conhecimento crítico dessa situação, sob a pena de se fazer "bancária" ou de pregar no deserto (2005b, p. 100, grifos nossos). 
Esta é a razão pela qual não são as "situações-limites", em si mesmas, geradoras de um clima de desesperança, mas a percepção que os homens tenham delas num dado momento histórico, como um freio a eles, como algo que eles não podem ultrapassar. No momento em que a percepção crítica se instaura, na ação mesma, se desenvolve um clima de esperança e confiança que leva os homens a se empenharem na superação das "situações-limites". (FREIRE, 2005b, p. 105).

As visões de mundo de educadores(as) e educandos(as), suas diferenças e modos de se confrontar são os temas que pautamos quando nos referimos à questão epistemológica.

Para Freire, quando nos referimos aos conhecimentos dos sujeitos da situação pedagógica, não há superioridade de um sobre o outro: ambos possuem lógicas diferentes e ambos são imprescindíveis para que o processo de ensino-aprendizagem seja bem sucedido em termos críticos.

Os conhecimentos que os educandos possuem a respeito do mundo, antes mesmo de tomar contato com o(a) educador(a) e suas aulas, são significações válidas, valiosas e legítimas, mas que devem ser confrontadas.

Quando, no processo de ensino, o educador se mostra indiferente a esses conhecimentos, invariavelmente fracassa nos seus propósitos. Isso ocorre, pois não entende que o conhecimento novo que pretende ensinar não ocupará um espaço vazio, um vácuo epistemológico na consciência dos(as) educandos(as). Ou seja, os(as) educandos(as) já operam com uma certa lógica na apreensão que fazem da realidade que os envolve. Essa apreensão tem um certo estatuto epistemológico: é uma visão de mundo que tem as suas raízes, motivações, influências, eficácias etc.

No entanto, em sociedades marcadas pela opressão, não há conhecimentos e práticas neutras. Todo conhecimento acrítico, que compreende a realidade de modo estático e, portanto, fatalista, acaba sendo omisso politicamente, colocando-se a favor da ordem vigente, da opressão instaurada. Por esse motivo, é necessário que haja um confronto epistemológico. A percepção de realidade dos educandos(as) passa a ser paulatinamente problematizada na medida em que os(as) educadores(as) expõem suas possíveis inconsistências, suas contradições, suas lacunas, mas também seus acertos de análise. Elementos novos que estavam ocultos nas considerações a respeito dos fatos, acontecimentos e processos começam a se fazer presentes em razão do confronto epistemológico protagonizado por sujeitos agentes (educador(a) e educando(a)) que conhecem e pronunciam o mundo.

Elementos não presentes no universo do(a) educador(a) refazem o conhecimento docente. Por outro lado, elementos antes ausentes do universo de percepção dos(as) 


\section{$e$-Curriculum}

educandos(as) começam a habitar a compreensão da realidade discente. Compreende criticamente a realidade aquele que capta a realidade existencial concreta de opressão em seu devenir histórico, em uma perspectiva de totalidade. Em outras palavras: compreensão dialética da realidade.

A nova compreensão da realidade não se dá, para Freire, por um processo de ruptura em que um saber novo se sobrepõe ao saber anterior. Pelo contrário, trata-se de um processo contínuo, gradual, processual (com perdão da redundância) de superação do saber que não se mostra mais consistente aos sujeitos. Ou seja, não é uma transição do não-saber para o saber. É a passagem de um "conhecimento de experiência feito" (FREIRE, 2005a) para um conhecimento crítico. E essa passagem ocorre na medida em que o saber de experiência feito é objeto de reflexão em que todos(as) os participantes são sujeitos.

Por isso, em Freire não há conhecimento crítico sem prática pedagógica crítica. Isso significa que os(as) próprios(as) educandos(as) são os(as) protagonistas, os sujeitos, os(as) agentes da transformação que se dá no universo de pensamento, da linguagem e da ação. $\mathrm{O}$ contexto criado pelo(a) educador(a), quando dialógico, favorece o exercício da criticidade. Em suma, a criticidade não é algo que se transmite. Ela é algo que se aprende, pratica e exerce. Tanto mais ela se aprofunda, quanto maiores são as condições que a Didática cria para o confronto epistemológico a partir da visão que os(as) educandos(as) possuem da sua realidade. Por isso, os dois conhecimentos importam no processo educativo: o do(a) professor(a) e os dos estudantes.

\section{ELEMENTOS DA DIDÁTICA FREIREANA NA PEDAGOGIA DO OPRIMIDO}

\subsection{Conteúdos da Didática Crítico-Libertadora}

Adentramos agora na instigante questão a respeito dos conteúdos da Didática CríticoLibertadora. Trata-se de um tema exaustivamente tratado por Freire na Pedagogia do Oprimido. Ousamos dizer que, junto com o tema da dialogicidade, é o principal aspecto praxiológico desta obra. Afinal, o que Freire denuncia quando trata da questão dos conteúdos educacionais? O que ele nos propõe?

Para o "educador-bancário", na sua antidialogicidade, a pergunta, obviamente, não é a propósito do conteúdo do diálogo, que para ele não existe, mas a respeito do programa sobre o qual dissertará a seus alunos. E a esta pergunta responderá ele mesmo, organizando seu programa (FREIRE, 2005b, p. 96). 
A denúncia de Freire recai sobre uma concepção e prática ainda hoje preponderantes no nosso sistema formal de educação: a de trabalhar com conteúdos programáticos selecionados sem consideração das necessidades objetivas e visões de mundo dos sujeitos concretos a quem eles se destinam. Aliás, a perspectiva preponderante tende a não ver os(as) educandos(as) como sujeitos. Para tal perspectiva, o conteúdo é proposto a partir de um ser humano abstrato. Os sujeitos reais, suas histórias pessoais e coletivas, suas expectativas, os contextos de onde são provenientes e, sobretudo, as visões de mundo que possuem sobre esses contextos são ignoradas ou, na melhor das hipóteses, apenas identificadas como tática de motivação, sem real influência nos processos de seleção de conteúdos.

Quando os conteúdos são selecionados por especialistas ou pelos próprios professores(as), independentemente de quais são as necessidades existenciais concretas do coletivo dos(as) educandos(as) e de suas comunidades, seja qual for a justificativa (de teor progressista ou conservador), a prática pedagógica tende a afastar os(as) estudantes do processo de conhecimento, pois nega o próprio modo de ser deste processo. Além disso, a prática tende a ser invasiva do ponto de vista cultural, já que impõe artefatos culturais sem sentido por não serem demandados pelos sujeitos e/ou não dialogarem diretamente com sua condição de vida e existência.

Por isso, Freire dedicou tantas páginas da Pedagogia do Oprimido para propor uma maneira de se realizar o processo de seleção do conteúdo programático a partir do universo sociocultural local. No quadro que segue, fizemos um esforço de síntese dos momentos de investigação temática proposto por ele a partir de certo momento do Capítulo 3.

Pode-se observar que o quadro está dividido em quatro colunas, sendo que cada uma delas tem um título (elaborado por nós) que representa as etapas sugeridas por Freire para o processo de busca dos temas geradores e para a seleção de conteúdos. Os tópicos enumerados em cada uma das etapas são as ideias que, de acordo com a nossa leitura, explicitam a linha de raciocínio desenvolvida por Freire para explicar cada um dos momentos da investigação dos temas geradores e da seleção dos conteúdos programáticos. Na parte inferior do quadro, explicitamos em forma de tópicos algumas considerações e esclarecimentos finais que Freire faz a respeito do processo. Por fim, esclarecemos que os parênteses após cada um dos tópicos por nós destacados têm a finalidade de facilitar a localização das informações no próprio Capítulo 3 da obra Pedagogia do Oprimido. Dessa forma, o(a) leitor(a) poderá cotejar a sistematização que realizamos e os blocos de parágrafos nos quais os tópicos foram baseados. 


\section{$e$-Curriculum}

Quadro 4 - Etapas da investigação dos temas geradores (FREIRE, 2005b)

\begin{tabular}{|c|c|c|c|}
\hline $\begin{array}{r}\mathbf{1}^{\mathbf{a}} \\
\text { Conh } \\
\text { contrad } \\
\text { pont } \\
\text { inv } \\
\text { speciali }\end{array}$ & $\begin{array}{l}\text { as } \\
\text { ido das } \\
\text { equipe } \\
\text { nos } \\
\text { nelas } \\
\end{array}$ & $\begin{array}{l}\text { os } \\
\text { a em } \\
\text { a }\end{array}$ & $\begin{array}{l}\text { : } \\
\text { r dos } \\
\text { a } \\
\text { los } \\
\text { ticos. } \\
6)\end{array}$ \\
\hline $\begin{array}{l}\text { 1.2. Reunião com pessoas } \\
\text { moradoras da região } \\
\text { (moradores, líderes } \\
\text { comunitários etc) para: } \\
(\$ \S 180-183) \\
\quad \text { - explicar o } \\
\text { porquê da investigação; } \\
\quad \text { - estimular para } \\
\text { que participem da } \\
\text { investigação como } \\
\text { auxiliares. } \\
\text { 1.3. Investigadores } \\
\text { iniciam suas visitas à área } \\
\text { como observadores } \\
\text { compreensivos. } \\
\text { (Descodificação ao vivo) } \\
\text { - (\$§184-192) }\end{array}$ & 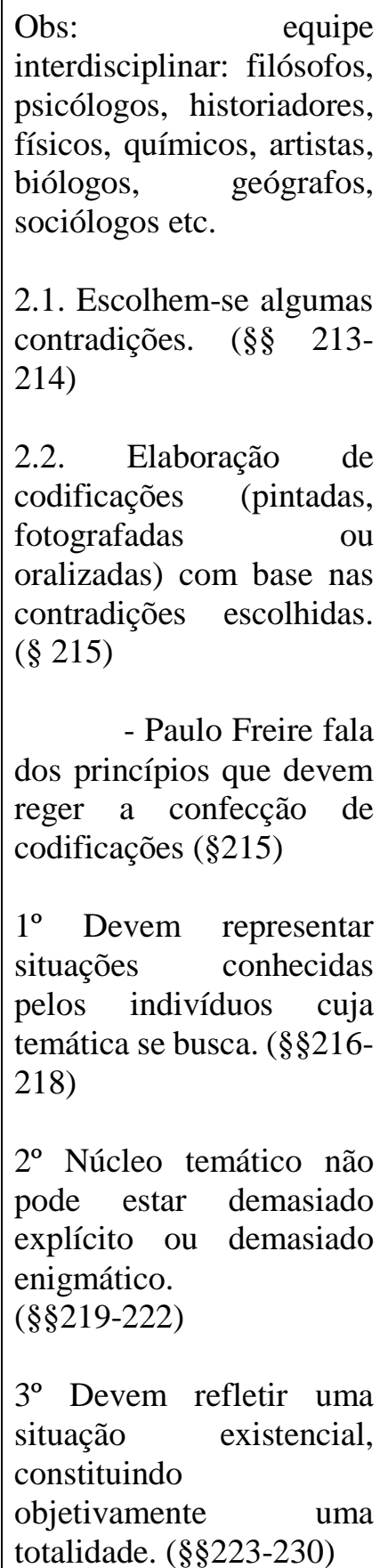 & 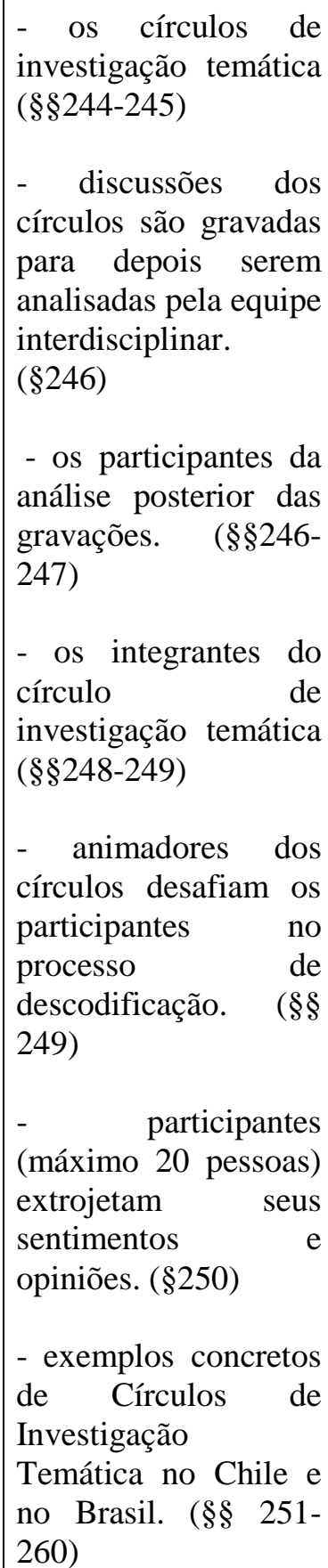 & 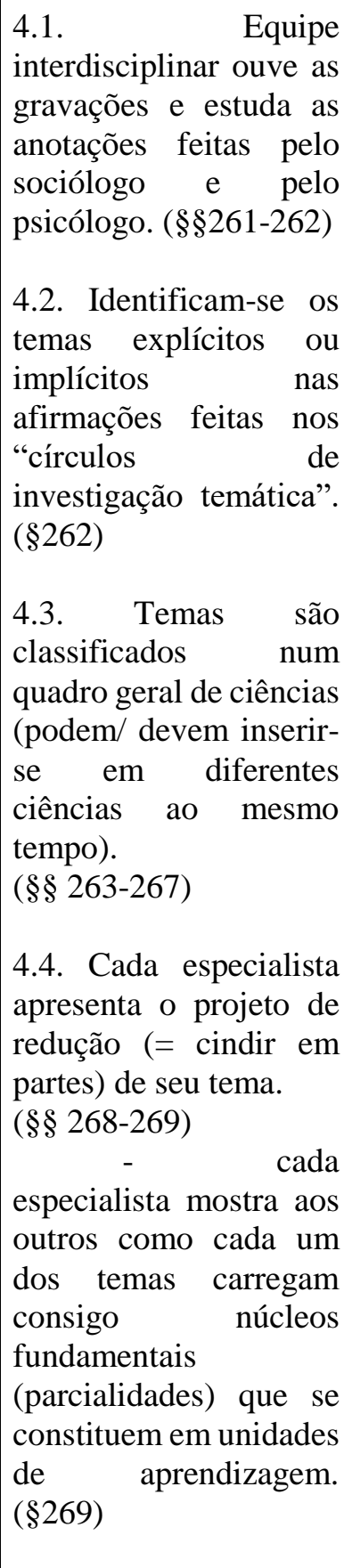 \\
\hline
\end{tabular}


1.5. Conteúdo de cada um dos relatórios é discutido pela equipe de investigação (inclusive com os investigadores auxiliares) em seminários avaliativos. ( $2^{\circ}$ momento da descodificação ao vivo $)$ - (\$§193-198)

- quanto mais se avalia, mais nos aproximamos das contradições principais e secundárias em que estão envolvidos os indivíduos da área.

1.6. Porque a temática significativa ainda não está constituída. $(\$ \$ 199$ 201)

1.7. A consciência real e a consciência máxima possível. (\$\$202-210)

1.8. Resultado da $1^{\mathrm{a}}$ etapa: apreensão mais ou menos aproximada do conjunto de contradições da área. (\$\$ 211-212)

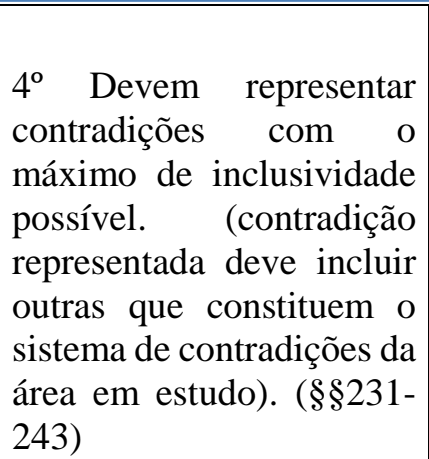

- especialistas sugerem uns aos outros inclusões à "redução" elaborada por cada um. (\$\$270-271)

$$
\text { - aí ocorre o }
$$
processo de inclusão dos "temas dobradiça" (facilitam compreensão entre dois temas ainda que não tenham sido sugeridos pelo povo durante a investigação da temática significativa). (\$\$272-275)

4.6. Codificação de cada tema reduzido (retotalização do tema cindido por meio da representação de situações existenciais). (\$\$276-277)

4.7. Confecção do material didático e situações de aprendizagem (fotografias, slides, cartazes, textos de leitura...). (\$278-286)

\section{ÚLTIMAS CONSIDERAÇÕES DE FREIRE:}

- Apresentação do programa de trabalho ao povo. (\$\$287-289)

- O que fazer quando não há como realizar esta prévia investigação temática. (\$\$290-299)

- O princípio que deve reger todo o processo: o programa deve ser buscado com o povo. (\$\$300-301)

Fonte: Elaborado pelos(as) autores(a)s com base em Freire (2005b).

Uma leitura atenta do quadro nos permite perceber a importância atribuída por Freire à questão da seleção dos conteúdos programáticos. Para uma educação que se pretende críticolibertadora e, portanto, compromissada com uma aprendizagem crítica, não é possível ensinar, senão a partir dos problemas coletivos vivenciados pela comunidade local e das visões que os sujeitos têm a respeito desses problemas. O quadro nos ajuda a compreender com muito mais clareza as seguintes palavras de Freire:

Para o educador-educando, dialógico, problematizador, o conteúdo programático da educação não é uma doação ou uma imposição - um conjunto 


\section{e-Curriculum}

de informes a ser depositado nos educandos -, mas a devolução organizada, sistematizada e acrescentada ao povo daqueles elementos que este lhe entregou de forma desestruturada.

A educação autêntica, repitamos, não se faz de A para B ou de A sobre B, mas de A com B, mediatizados pelo mundo. Mundo que impressiona e desafia a uns e a outros, originando visões ou pontos de vista sobre ele. Visões impregnadas de anseios, de dúvidas, de esperanças ou desesperanças que implicitam temas significativos, à base dos quais se constituirá o conteúdo programático da educação (2005b, p. 96-97, grifos nossos).

O conteúdo programático em Freire é selecionado, organizado e sequenciado a partir dos vários elementos que a investigação temática oferece ao(à) educador(a). Ou seja, não se trata de uma adequação dos dados provenientes da realidade a conteúdos pré-existentes, tal como várias leituras equivocadas de Freire sugerem. Trata-se efetivamente de selecionar tópicos de conhecimentos sistematizados (e de preparar materiais didáticos) demandados pela experiência vivencial dos sujeitos e identificados criticamente pelo(a) educador(a) como necessários para a compreensão crítica dos problemas comunitários. Esses tópicos muitas vezes não estão presentes nos currículos padronizados, o que faz da prática docente uma atividade intelectual criativa.

Em suma, os "temas significativos" orientam de tal modo o trabalho de seleção do conteúdo programático, que não são os sujeitos, educador(a) e educandos(as), que servem ao conteúdos e sim os conteúdos que servem aos sujeitos, entendidos, antes de tudo, como sujeitos coletivos.

\subsection{Método da Didática Crítico-Libertadora}

O problema do método no contexto didático tem a ver com o modo ou com a forma de se ensinar, aprender e produzir conhecimento na situação de aula. Os pressupostos apresentados no item 3 e o subitem 4.1 já anunciaram o diálogo como princípio metodológico indispensável à Didática Crítico-Libertadora. Agora, trata-se de explicitar a dialogicidade, demonstrando de que modo Freire rejeita o antidiálogo e afirma do diálogo em toda a sua radicalidade.

Se os líderes revolucionários de todos os tempos afirmam a necessidade do convencimento das massas oprimidas para que aceitem a luta pela libertação - o que de resto é óbvio -, reconhecem implicitamente o sentido pedagógico desta luta. Muitos, porém, talvez por preconceitos naturais e explicáveis contra a pedagogia, terminam usando, na sua ação, métodos que são empregados na "educação" que serve ao opressor. Negam a ação pedagógica no processo de libertação, mas usam a propaganda para convencer... (2005b, p. 62). 
Eis aí nesta citação a denúncia a uma das maiores contradições na qual recaem muitos(as) educadores(as) que se dizem comprometidos(as) com uma perspectiva emancipatória: dicotomizar discurso crítico da prática dialógica, como se fosse possível falar em sociedade sem opressores e oprimidos, utilizando-se do método pedagógico opressor.

O antidiálogo instaura entre educador(a) e educandos(as) uma relação de subserviência dos segundos em relação ao primeiro. Quando educandos(as) percebem que a indagação, a discordância, a contraposição ao(à) educador(a) criam um clima de desconforto no ambiente pedagógico, ou quando escutam do professor que estudantes devem sentar, ouvir e obedecer, pois ainda não estão preparados para questionar o conhecimento produzido pelas grandes mentes da humanidade, ou quando sentem que não devem questionar certas práticas do(a) professor(a) com medo de retaliações, ou quando observam a indiferença do(a) professor(a) em relação aos(às) sujeitos com que está trabalhando, ou quando percebem que o(a) educador(a) é dialógico apenas quando lhe convém, mas não se abre para a escuta em outras questões (demonstrando, portanto, uma pseudodialogicidade), ou enfim, quando o(a) professor(a) produz no(a) educando(a) o sentimento de medo, sabendo que contrariá-lo(a) levará a perseguições, perda de oportunidades futuras, "fechamento de portas" etc., em todos esses casos temos a expressão cristalina da antidialogicidade.

Por outro lado, Freire afirma o diálogo como princípio didático-pedagógico por razões que vão muito além de mera tática motivacional.

Se é dizendo a palavra com que, "pronunciando" o mundo, os homens o transformam, o diálogo se impõe como caminho pelo qual os homens ganham significação enquanto homens.

Por isto, o diálogo é uma exigência existencial. E, se ele é o encontro em que se solidarizam o refletir e o agir de seus sujeitos endereçados ao mundo a ser transformado e humanizado, não pode reduzir-se a um ato de depositar ideias de um sujeito no outro, nem tampouco tornar-se simples troca de ideias a serem consumidas pelos permutantes.

Não é também discussão guerreira, polêmica, entre sujeitos que não aspiram a comprometer-se com a pronúncia do mundo, nem buscar a verdade, mas impor a sua.

[...] É um ato de criação. Daí que não pode ser manhoso instrumento de que lance mão um sujeito para a conquista do outro. A conquista implícita no diálogo é a do mundo pelos sujeitos dialógicos, não a de um pelo outro. Conquista do mundo para a libertação dos homens (FREIRE, 2005b, p. 91).

O diálogo corporeifica o compromisso axiológico com a humanização, o projeto político de superação das relações sociais de opressão, o processo gnosiológico do sujeito encarnado 


\section{$e$-Curriculum}

como produtor de significação do mundo, o reconhecimento epistemológico da legitimidade dos saberes e das lógicas que se encontram e se confrontam no contexto pedagógico.

O diálogo exige que o ponto de partida seja o universo existencial dos(as) estudantes, pois ele não pode ser artificial. Ou seja, o diálogo é autêntico quando os(as) educandos(as), ao perceberem que a sua realidade, o seu contexto de vida coletiva, estão sendo problematizados e exige dele uma resposta tanto no nível da reflexão quanto no nível da ação.

É importante dizer que o diálogo como caminho indispensável da Didática CríticoLibertadora não impede o recurso às diversas técnicas e o uso dos diversos recursos pedagógicos que historicamente foram desenvolvidos pelo pensamento e pelo exercício da Didática. Uso de filmes, slides, trabalhos em grupo, aulas expositivas com todas as suas variações, seminários, leituras em sala de aula etc. não estão excluídos como estratégias didático-pedagógicas. Na perspectiva freireana, o necessário é que o diálogo esteja presente sejam quais forem as técnicas e os recursos utilizados.

Por fim, queremos ressaltar que o diálogo não elimina a diferença existente entre educador(a) e educandos(as), porém exclui a desigualdade que historicamente tem colocado esses polos em situação de antagonismo, com preponderância do professor como centro de poder e de conhecimento na relação. Professores(as) e estudantes não são idênticos, pois têm funções diferentes a desempenhar. Porém, isso não significa que são desiguais. É o diálogo que permite que o clima de horizontalidade se instaure nessa relação, de tal modo que vá ficando cada vez mais claro para educadores(as) e educandos(as) que o normal das relações humanas é a vivência da igualdade política, por meio da qual todos(as) possam se perceber cada vez mais como sujeitos dos rumos da vida coletiva. Ainda, é importante destacar que tais concepções e práticas não atentam contra a autoridade do educador(a), mas a reafirmam em outras bases. Agora já não há uma exacerbação da autoridade que a transforma em autoritarismo, mas a verdadeira autoridade dada pela prática libertadora de busca coletiva, liderada pelo educador(a), de aproximação aos objetos de conhecimento que se caracterizam significativos a todos(as) que vão aprender naquela determinada situação.

\subsection{Avaliação na Didática Crítico-Libertadora}

Em seu percurso desde os primeiros grupos coletores e caçadores os/as humanos/as acostumaram-se a considerar os prós, contras, erros, acertos e aprendizagens acumuladas para realizar julgamentos e tomar decisões, ou seja, realizavam avaliação. Cada indivíduo a praticava para guiar suas ações 
no cotidiano e aprender cada vez mais e melhorar tanto as próprias formas de aprender, de realizá-las, quanto seus resultados (SILVA, 2011, p. 59).

O ser humano avalia sua ação para aprender com ela e para transformá-la e ao mundo. A avaliação é, assim, instrumento humano de busca por fazer melhor e, como ser inconcluso, fazer-se melhor. É condição indispensável à superação dos limites impostos pela realidade no caminho para "ser mais". Nesse sentido, concordamos com Gadotti (1987, p. 7) quando afirma que "[...] refletir é também avaliar, e avaliar é também planejar, estabelecer objetivos.". Destaca-se, então, o caráter eminentemente humano da avaliação e sua pertença ao processo mesmo de conhecimento envolvendo desde as questões mais elementares do dia a dia até a organização do ensino e da aprendizagem formalizada em situação escolar. Ou como diz Freire (2005b, p. 84) "Aí se encontram as raízes da educação mesma, como manifestação exclusivamente humana.".

A avaliação é, portanto, em Freire, um instrumento humano de reflexão sobre a prática a fim de construir práticas num só tempo diferentes e melhores que as primeiras. É, também, processo contínuo de busca por "ser mais", melhorar as condições objetivas, de agir sobre a realidade. A avaliação é forma de, refletindo sobre a prática e os juízos de senso comum que a inspiram e organizam, buscar elementos para a superação destas, produzindo práticas e juízos críticos que, alterando o nível de consciência, a transformam em consciência crítica. Entendemos que o trecho a seguir corrobora nossa análise:

[...] [a educação] problematizadora parte exatamente do caráter histórico e da historicidade dos homens. Por isto mesmo é que os reconhece como seres que estão sendo, como seres inacabados, inconclusos, em e com uma realidade, que sendo histórica também, é igualmente inacabada. $\mathrm{Na}$ verdade, diferentemente dos outros animais, que são apenas inacabados, mas não são históricos, os homens se sabem inacabados. Têm a consciência de sua inconclusão. Aí se encontram as raízes da educação mesma, como manifestação exclusivamente humana. Isto é, na inconclusão dos homens e na consciência que dela têm. Daí que seja a educação um que-fazer permanente. Permanente, na razão da inconclusão dos homens e do devenir da realidade (FREIRE, 2005b, p. 83-84, grifos nossos).

Reforçar que esse processo humano geral inspira a avaliação na perspectiva críticolibertadora significa destacar mais uma vez sua natureza humanizadora. Também que a avaliação expressa o processo pedagógico desenvolvido, a didática empregada, desde as concepções até as práticas mais comuns e rotineiras. Não é possível imaginar numa prática bancária a avaliação diagnóstica ou formativa, mas uma avaliação somativa baseada em fortes critérios de controle, classificação e seleção. Assim, uma avaliação que rompa com as práticas 


\section{$e$-Curriculum}

da Educação Bancária e consagre a máxima cunhada por Fernandes (2009) de "Avaliar para Aprender" deve assumir os pressupostos freireanos da educação como processo de conhecimento que visa à transformação social.

Assim, buscando aprofundar o caminho para aproximarmo-nos de uma concepção de avaliação crítico-libertadora como elemento da Didática Crítico-Libertadora, entendemos que o tema da avaliação aparece na Pedagogia do Oprimido, pelo menos, de duas formas: de modo geral, quando, no decorrer de toda obra, anuncia a educação problematizadora como açãoreflexão-ação; de modo mais pontual quando fala do que se espera de um trabalho bem sucedido de educação fundamentada da Didática Crítico-Libertadora.

Ora, quando as relações sociais concretas dos sujeitos e o objeto sobre o qual incidem os atos cognoscentes do(a) educador(a) e dos(as) educandos(as) é o ponto de partida, trata-se de um momento de reflexão crítica sobre a prática. Ou seja, trata-se de um momento de avaliação em que os sujeitos afastam-se da realidade em que estão imersos para vê-la melhor. A ação é objeto da reflexão. No entanto, como o compromisso é com a transformação da realidade, a reflexão não para na constatação. Ela vislumbra novos caminhos, alternativas, soluções possíveis, ou seja, novas ações dos sujeitos diante dos problemas que os desafia.

A educação problematizadora se faz, assim, um esforço permanente através do qual os homens vão percebendo, criticamente, como estão sendo no mundo com que e em que se acham.

Se, de fato, não é possível entendê-los fora de suas relações dialéticas com o mundo, se estas existem independentemente de se eles as percebem ou não, e independentemente de como as percebem, é verdade também que a sua forma de atuar, sendo esta ou aquela, é função, em grande parte, de como se percebam no mundo (FREIRE, 2005b, p. 82-83).

Esse trecho nos revela que a problematização da realidade local e seu estudo são em si práticas avaliativas, os seminários sobre a realidade e o processo que conduz ao "ser mais" se faz com avaliação. Ora, não existe projeto educativo desprovido de intencionalidade. É daquilo que pretendemos para a educação que podemos extrair os critérios para avaliar se estamos no caminho certo ou se nos desviamos da finalidade projetada.

[...] a prática problematizadora [...] propõe aos homens sua situação como problema. Propõe a eles sua situação como incidência de seu ato cognoscente, através do qual será possível a superação da percepção mágica ou ingênua que dela tenham. A percepção ingênua ou mágica da realidade da qual resultava a postura fatalista cede seu lugar a uma percepção que é capaz de perceber-se. $[\ldots]$ 
Desta forma, aprofundando a tomada de consciência da situação, os homens se "apropriam" dela como realidade histórica, por isto mesmo, capaz de ser transformada por eles.

O fatalismo cede, então, seu lugar ao ímpeto de transformação e de busca, de que os homens se sentem sujeitos (FREIRE, 2005b, p. 85).

Tal como fica evidenciado no trecho citado, possibilitar que os indivíduos se tornem cada vez mais sujeitos do processo histórico em que se encontram é o grande objetivo da perspectiva libertadora de educação. Portanto, não se trata de um objetivo meramente performático. Trata-se um objetivo praxiológico.

A avaliação na Didática Crítico-Libertadora quer, superando as perspectivas individualistas do aprender e do praticar/fazer, compreender avanços e limites dos sujeitos do processo pedagógico explicitando se e como estão se tornando conscientes da necessidade da organização coletiva para superação das situações de opressão. E, se também se tornam criadores de soluções para esses problemas que produzem a desumanização.

No processo em que se busca a formação dos sujeitos críticos que vivam a "plenitude da práxis" é evidente que são necessários momentos de leitura, criação artística, desenvolvimento físico-motor, resolução de problemas lógico-matemáticos etc. Porém, essas múltiplas aprendizagens não ocorrem no vazio nem se justificam por si mesmas. Elas estão implicadas no propósito maior da Didática Crítico-Libertadora: a formação de sujeitos históricos, que se assumem coletivamente no processo de aprender-ensinar e ensinar-aprender tendo em vista a superação da realidade social injusta.

Ora, na Didática Critico-Libertadora o encontro dialógico educador(a) e educandos(as), mediatizados pela realidade, tendo em vista a sua transformação precisa ser constantemente avaliado criticamente pelos sujeitos que dele fazem parte. Do contrário, o processo entra em contradição com o seu propósito. Por isso, todos são sujeitos da avaliação que se faz da práxis individual e coletiva do aprender-ensinar-aprender. Os processos e os resultados coletivos e individuais não são vistos como de exclusiva responsabilidade de um ou de outro sujeito da relação educador(a)/educando(a). Os sucessos pertencem a todos(as) e os insucessos também.

Enfim, a avaliação na Didática Crítico-Libertadora não tem a função de medir classificar, punir, hierarquizar ou selecionar. Ela é momento de compreender como está se desenvolvendo a práxis coletiva, como o indivíduo se coloca no processo e, sobretudo, analisar como as aprendizagens estão possibilitando ações na realidade concreta. Quanto mais os sujeitos se verem como capazes de nela intervir (inserção crítica), tanto mais o projeto educativo 


\section{$e$-Curriculum}

estará coerente consigo mesmo. Colocar luz sobre esse processo é o que se pode esperar da avaliação na Didática Crítico-Libertadora.

\subsection{Relações interpessoais educadores(as)-educandos(as) na Didática Crítico-Libertadora}

A questão das relações interpessoais entre educador(a)-educandos(as) nos remete às tensões inevitáveis, aos conflitos, às expectativas em choque, às afetividades que, invariavelmente, exigem tomadas de decisões por parte dos(as) educadores(as) no exercício da Didática.

Em Pedagogia do Oprimido, Freire tratou dessa questão recorrendo, principalmente, a dois conceitos: autoridade e liberdade. A Didática Crítico-Libertadora defende que os extremos da hipertrofia da autoridade, que é o autoritarismo, e da hipertrofia da liberdade, que é a permissividade ou licenciosidade, só podem ser evitados quando, nas relações entre educador(a) e educandos(as) exista uma não-dissociação entre a liberdade e a autoridade. No trecho a seguir Paulo Freire se refere a essa questão compreendendo que a relação pedagógica não acontece somente nos espaços de sala de aula, mas também nos diversos contextos em que a ação educativa se dá e que, inevitavelmente, precisa lidar com a tensa relação entre autoridade e liberdade.

É por isso que a verdadeira autoridade não se afirma como tal na pura transferência, mas na delegação ou na adesão simpática. Se se gera um ato de transferência, ou de imposição "anti-pática" sobre as maiorias, se degenera em autoritarismo que esmaga as liberdades.

Somente ao existenciar-se como liberdade que foi constituída em autoridade, pode evitar seu antagonismo com as liberdades.

Toda hipertrofia de uma provoca a atrofia da outra. Assim como não há autoridade sem liberdade e esta sem aquela, não há autoritarismo sem negação das liberdades e licenciosidade sem negação da autoridade.

$\mathrm{Na}$ teoria da ação dialógica, portanto, a organização, implicando autoridade, não pode ser autoritária; implicando liberdade, não pode ser licenciosa (FREIRE, 2005b, p. 206-207, grifos nossos).

A autoridade pedagógica autêntica se forja não pelo cargo que ocupa e sim pelo reconhecimento daqueles(as) que vão percebendo nela alguém que respeita as liberdades. Ou seja, a autoridade não se funda na obediência dos(as) educandos(as) que a temem e sim na adesão deles(as) às propostas pertinentes que o(a) educador(a) vai fazendo no decorrer da convivência com os(as) estudantes. A possibilidade de dialogar sobre suas propostas e perspectivas é o que vai testemunhando aos(às) educandos(as) o respeito do(a) educador(a) pelas suas liberdades. 
A experiência da liberdade é o que vai dar as condições e legitimidade ao exercício da autoridade. Portanto, Freire não nega a necessidade de que a autoridade coloque limites e regras, e faça valer esses limites e regras. No entanto, os próprios limites e regras só são legítimos quando compreendidos na sua razão de ser pelos próprios educandos(as) que a eles estarão submetidos. Só assim pode-se afirmar que os limites e regras estão fundados na liberdade e não no autoritarismo arbitrário.

Ou seja, a liberdade produz e compreende as regras que deverão regular a convivência coletiva, reconhecendo na autoridade a legitimidade de zelar por elas. A autoridade, portanto, funda-se na liberdade, restringindo os atos licenciosos que são, na verdade, desvios da liberdade que, por definição, só pode ser exercida em consonância com limites que preservam a vida e dignidade coletivas.

Tão equivocado quanto a degeneração da liberdade em licenciosidade nas nossas salas de aula nos tempos atuais é o anseio pelo retorno do autoritarismo. Uma pequena concessão que se faz ao autoritarismo é brecha que se abre para que ele se instale nas suas versões mais ilimitadas e perversas, seja no nível micropolítico da aula, seja no mesopolítico da escola ou no macropolítico do sistema de ensino e do Estado. O mesmo docente que saúda o autoritarismo no contexto pedagógico é aquele que reclama das arbitrariedades a que está submetido, enquanto profissional diante dos seus superiores hierárquicos, e enquanto categoria diante do poder público.

Portanto, para a Didática Crítico-Libertadora, a sala de aula, como uma forma de organização, não pode ser um espaço autoritário, nem licencioso. Precisa ser um espaço democrático em que se vivenciam relações democráticas. Essa exigência também se coloca para a escola e as estruturas do sistema de ensino. A vivência democrática não prescinde da liberdade, tampouco da autoridade. O exercício da autonomia dos(as) educandos(as) na sala de aula, como na escola, é indispensável para que os sujeitos se formem como seres humanos autônomos. Portanto, a autonomia é um aprendizado praxiológico.

Como em todo espaço democrático de convivência coletiva, as regras e os limites existem. Ambas são construções coletivas dos próprios sujeitos no exercício das suas liberdades (de escolher, de decidir, de opinar, de discordar, de concordar, de argumentar, de votar, de participar da assembleia de escola e da assembleia de classe etc.). Estabelecidas essas regras e limites, nessas condições, a autoridade tem um papel fundamental de dar o exemplo ao seguilas e fazer com que sejam respeitadas ao observar que estão sendo violadas. Só assim poder ser 


\section{$e$-Curriculum}

superado o regime de força típico do autoritarismo e o sistema de individualismo total típico da lógica "liberticida" (CORTELLA, 2003, p. 156) do "cada um por si".

\section{CONCEITUANDO DIDÁTICA A PARTIR DA PEDAGOGIA DO OPRIMIDO}

Com base nas considerações e análises que fizemos até este momento do ensaio tornase possível explicitarmos uma proposta de conceituação de Didática Crítico-Libertadora Freireana que emerge da Pedagogia do Oprimido.

No entanto, antes de apresentarmos a nossa formulação, concentremo-nos no trecho que segue.

Se, na educação como situação gnosiológica, o ato cognoscente do sujeito educador (também educando) sobre o objeto cognoscível não morre, ou nele se esgota, porque, dialogicamente, se estende a outros sujeitos cognoscentes, de tal maneira que o objeto cognoscível se faz mediador da cognoscitividade dos dois, na teoria da ação revolucionária se dá o mesmo. Isto é, a liderança tem, nos oprimidos, sujeitos também da ação libertadora e, na realidade, mediação da ação transformadora de ambos (FREIRE, 2005b, p. 146-147).

Nessa passagem podemos identificar alguns elementos marcantes da concepção freireana de Didática: o encontro, o diálogo, os sujeitos, os atos cognoscentes, a realidade que mediatiza a relação dialógica, o horizonte da ação transformadora, no limite, revolucionária.

Com base no exposto no decorrer do ensaio, propomos um conceito de Didática CríticoLibertadora como: encontro dialógico de sujeitos, educadores(as)-educandos(as), que realizam seus atos cognoscentes no contexto de aula, mediatizados pelo mundo, dialetizado pela relação entre liberdade e autoridade, tendo como ponto de partida a percepção de realidade dos(as) educandos(as) sobre suas situações-limites, que se encontra e confronta com a percepção do(a) educador(a), que seleciona conhecimentos crítico-significativos, e que tem como horizonte ético-político a inserção crítica dos sujeitos em favor da transformação social que supera a realidade opressora e se constitui como condição para a realização da vocação do ser humano para "ser mais".

Se fizermos uma leitura atenta da proposição acima, perceberemos que todos os pressupostos e elementos da Didática apresentados neste ensaio estão nela presentes.

O pressuposto axiológico e o pressuposto político se explicitam no momento em que afirmamos que a Didática Crítico-Libertadora "tem como horizonte ético-político a inserção crítica (práxis transformadora) dos sujeitos em favor da transformação social que supera a 
realidade opressora e se constitui como condição para a realização da vocação do ser humano para 'ser mais"', que foram apresentados nos subitens 3.1 e 3.2.

O pressuposto gnosiológico é explicitado no momento em que afirmamos que se trata do "encontro dialógico" no qual educadores(as) e educandos(as) "realizam seus atos cognoscentes no contexto de aula mediatizados pelo mundo", sobre o qual dissertamos no subitem 3.3.

O pressuposto epistemológico se revela no momento em que evidenciamos que se trata do "encontro dialógico de educadores(as)-educandos(as)" e que tem "como ponto de partida a percepção de realidade dos(as) educandos(as)", demonstrando que há dois sujeitos do conhecimento com saberes diferentes e legítimos que se encontram: há duas epistemologias, sobre as quais refletimos no subitem 3.4.

O conteúdo da Didática Crítico-Libertadora fica claro quando afirmamos que o encontro tem "como ponto de partida a percepção de realidade dos(as) educandos(as) sobre suas situações-limites, que se encontra e confronta com a percepção do(a) educador(a), que seleciona conhecimentos crítico-significativos". Esse aspecto tivemos a oportunidade de desenvolver no subitem 4.1.

O método da Didática Crítico-Libertadora fica evidenciado quando reiteramos que se trata do "encontro dialógico de educadores(as)-educandos(as) e educandos(as)educadores(as), [...] mediatizados pelo mundo", sendo que este ponto pudemos apresentar no subitem 4.2 .

A avaliação da Didática Crítico-Libertadora se expressa quando deixamos claro que se trata de uma Didática que visa à "inserção crítica (práxis transformadora) dos sujeitos coletivos em favor da transformação social", como critério ético-crítico de avaliação do trabalho pedagógico. Sobre esse ponto discorremos no subitem 4.3.

\section{As relações educador(a)-educandos(as) da Didática Crítico-Libertadora} explicitam-se quando afirmamos que o encontro dialógico é "dialetizado pela relação entre liberdade e autoridade", tal como pudemos desenvolver no subitem 4.4.

É evidente que o conceito aqui proposto não tem a pretensão de ser definitivo, tampouco consensual, entre os estudiosos de Freire e da Didática. Ele é uma possibilidade de explicitação que foi se constituindo na medida em que íamos desenvolvendo a nossa reflexão sobre a Didática Freireana. 


\section{$e$-Curriculum}

\section{CONSIDERAÇÕES FINAIS}

Nossa experiência como educadores da Educação Básica pública e da Educação Superior tem nos mostrado que é sim possível fazer a Didática Crítico-Libertadora na sala de aula e que os limites político-institucionais não são suficientes para impedir essa iniciativa. É claro que essa possibilidade só se realiza quando o professor assume isso como um desejo, adere a essa concepção e busca descobrir os princípios e modos de fazê-la.

Quando nos arriscamos a praticá-la com os nossos alunos na sala de aula, muito rápido percebemos a diferença. Muito rápido os estudantes reconhecem que a vida deles começou a ser objeto de estudo na sala de aula e motivam-se a interagir.

Nesse sentido, quem primeiro legitima a Didática Crítico-Libertadora são os(as) estudantes. Só depois dessa legitimação junto a eles(as) que nós vamos conquistando legitimidade junto à escola. Quando começamos a mostrar para os gestores(as) da escola os resultados de aprendizagem que estamos alcançando nas suas várias dimensões (cognitiva, afetiva, ética, política, estética etc.), a própria gestão tende a reconhecer que aquela Didática, que se contrapõe às fórmulas impostas pelo sistema, é muito mais bem sucedida do que a Didática hegemônica que tem sido praticada pela maioria dos educadores e educadoras.

Em síntese, buscamos demonstrar que na Didática Crítico-Libertadora que emerge da Pedagogia do Oprimido o ponto de partida e de chegada é a realidade existencial concreta dos(as) educandos(as) com quem trabalhamos.

Ao desvelarmos dialogicamente com eles(as) essa realidade, suas determinações, as causas dos problemas que ela possui e vislumbrarmos caminhos para a superação de tais problemas, estaremos contribuindo de modo significativo com a formação de sujeitos coletivos engajados.

A formação de sujeitos coletivos que se organizam para lutar contra as situações de opressão que recaem sobre as comunidades, a cidade, o estado, o país e sobre o planeta é o grande objetivo da Pedagogia do Oprimido de Paulo Freire. Aí está a relação possível entre a redução das desigualdades sociais que é um problema macrossocial e a Didática CríticoLibertadora que se dá no nível local da sala de aula.

Ou seja, não é a adaptação dos sujeitos aos processos vigentes de seletividade social que poderá contribuir com a redução das desigualdades sociais. Essa mera adaptação não contribui com a redução das desigualdades. As desigualdades não são enfrentadas pelo "cada um por si" e pelo "salve-se quem puder". 
As desigualdades são realmente enfrentadas quando as comunidades se organizam e lutam para que (dentre outras coisas) o fundo público seja destinado à resolução dos problemas comunitários, municipais, estaduais etc., sejam eles de saúde, transporte, moradia, segurança, alimentação etc.

Em suma, lutar contra as desigualdades por meio da educação não significa adaptar estudantes para uma competição desigual cujos critérios de seletividade beneficiam os que já nasceram privilegiados. Pelo contrário, significa contribuir para que os estudantes se vejam como sujeitos coletivos e, portanto, sujeitos históricos que podem transformar a realidade quando se juntam, contestam a ordem e propõem alternativas a ela. 


\section{$e$-Curriculum}

\section{REFERÊNCIAS}

CANDAU, Vera Maria. (org.). Didática crítica intercultural: aproximações. Petrópolis, RJ: Vozes, 2012.

CASTRO, Amelia Domingues de; CARVALHO, Anna Maria Pessoa de. (orgs.). Ensinar a ensinar: didática para a escola fundamental e média. São Paulo: Pioneira Thomson Learning, 2005.

CORDEIRO, Jaime. Didática. São Paulo: Contexto, 2009.

CORTELLA, Mario Sergio. A escola e o conhecimento: fundamentos políticos e epistemológicos. 7 ed. São Paulo: Cortez: Instituto Paulo Freire, 2003.

FERNANDES, Domingos. Avaliar para aprender: fundamentos, práticas e políticas. São Paulo: Editora UNESP, 2009.

FREIRE, Paulo. Pedagogia da Autonomia: saberes necessários à prática educativa. 31. ed. São Paulo: Paz e Terra, 2005a.

Pedagogia do Oprimido. 41.ed. Rio de Janeiro, Paz e Terra, 2005b.

GADOTTI. Moacir. Prefácio. In: DEMO, Pedro. Avaliação Qualitativa. São Paulo: Cortez, 1987.

GASPARIN, João Luiz. Uma didática para a Pedagogia Histórico-Crítica. 5. ed.

Campinas, SP: Autores Associados, 2011.

LIBÂNEO, José Carlos. Didática. São Paulo: Cortez, 1994.

Ensinar e aprender, aprender e ensinar: o lugar da teoria e da prática em didática. In: LIBÂNEO, José Carlos; ALVES, Nilda (Orgs.). Temas de pedagogia: diálogos entre didática e currículo. São Paulo: Cortez, 2012.

MATOS, Sônia Regina da Luz. Didática e suas forças vertiginosas. Revista Conjectura, Caxias do Sul (RS), v. 14, n. 1, p. 93-134, 2009.

MELO, Alessandro de; URBANETZ, Sandra Terezinha. Fundamentos de didática. Curitiba: InterSaberes, 2012.

SAUL, Ana Maria; SAUL, Alexandre. O saber/fazer docente no contexto do pensamento de Paulo Freire: contribuições para a Didática. Caderno de Pesquisa, São Luís (MA), v. 24, n. 1, p 1-13, 2017.

SILVA, Itamar Mendes. Avaliação Qualitativa Formativa: o portfólio que promove a aprendizagem. In: TAVARES, Mari Inês. (Org.). Estágio Supervisionado 1. 1. ed.: UFES/NEAD, 2011. 